\title{
Tingkat Kesadaran Privasi Atas Masalah Keamanan Informasi ( Lack Of Security Awareness)
}

\author{
John Reimon Batmetan, Brenda Kariso, Michelle Moningkey, Afriane Tumembow
}

Pendidikan Teknologi Informasi dan Komunikasi, Universitas Negeri Manado, Tondano 95318

john.reimon@gmail.com, brendakarisoh1998@gmail.com, mmoningkey81@gmail.com, afrianetbw@gmail.com

\begin{abstract}
ABSTRAK
Selalu ada aspek negatif dari sebuah pemanfaatan teknologi. Teknologi informasi tidak lepas dari masalah ini. Ada banyak manfaat dari teknologi informasi. Sayangnya salah satu aspek negatifnya adalah masalah keamanan (security). Seiring dengan perkembangan teknologi informasi dan bertambahnya layanan online yang diakses oleh masyarakat, istilah privasi menjadi lebih familiar. Tujuan dari penelitian ini adalah untuk menganalisis dan mengukur pemahaman Mahasiswa tentang pentingnya pemahaman tentang kebijakan privasi pada layanan publik. Metode yang digunakan pada penelitian ini adalah metode survey. Survey dilakukan dengan cara mengumpulkan data hasil survei mahasiswa PTIK UNIMA. Penelitian ini dilakukan secara langsung (tatap muka) maupun secara online (tanpa tatap muka). Hasil penelitian ini menunjukan bahwa sebagian besar mahasiswa menyadari pentingnya keamanan privasi dalam layanan public, mahasiswa juga menyadari resiko yang dapat terjadi jika melakukan pelanggaran dalam kebijakan privasi orang lain. Namun tidak sedikit juga mahasiswa yang merasa tidak peduli dengan keamanan privasi mereka.
\end{abstract}

Kata Kunci : Keamanan Informasi, Security, Privasi, UNIMA, survey

\section{PENDAHULUAN}

Banyak orang beranggapan bahwa masalah keamanan informasi dapat dipecahkan dengan membeli produk keamanan, misalnya firewall, anti-virus, dan seterusnya. Kemanan informasi sebetulnya adalah sesuatu yang akan kita amankan disebut dengan "aset". Untuk itu, langkah pertama dalam pengamanan adalah menentukan asset yang ingin dilindungi yaitu informasi pribadi. Penelitian ini akan mengukur tingkat kesadaran mahasiswa terhadap keamanan informasi.[1]Privasi masih menjadi konsep yang asing bagi banyak pengguna layanan online, meskipun istilah ini sering menjadi bahan pembicaraan. Kesadaran tentang privasi juga lekat hubungannya dengan kebebasan berekspresi dan isu keamanan. Sikap tidak peduli dan menganggap bahwa privasi bukan sesuatu yang penting bisa didasari oleh ketidaktahuan tentang ancaman dan risiko terhadap privasi seseorang[2].
Ada beberapa prinsip utama dalam keamanan informasi, yaitu :

a. Aspek Keamanan : Ketika kita berbicara tentang keamanan informasi, maka yang kita bicarakan adalah tiga hal; confidentiality, integrity, dan availability. Ketiganya sering disebut dengan istilah CIA. Prioritas dari ketiga aspek tersebut berbeda-beda untuk jenis sistem dan organisasi yang menggunakannya. Ada sistem yang aspek integrity lebih penting daripada kerahasiaannya (confidentiality). Ini adalah prinsip utama dari keamanan.

b. Aspek Keamanan Lainnya : Selain ketiga aspek utama (CIA), ada aspek keamanan lainnya yang ini sifatnya tambahan, meskipun kadang menjadi bagian yang cukup signifikan juga, yaitu : Non-repudation atau nir-sangkal, Authentication, dan Authorization. [1]

Menyadari risiko keamanan personal informasi yang disebabkan oleh perilaku 
membagikan informasi di media sosial atau situs jejaring internet, banyak penelitian yang telah dilakukan. Salah satunya adalah penelitian dengan judul "Examining the Security Awareness, Information Privacy, and the Security Behaviors of Home Computer Users “ oleh Edwards (2015), namun penelitian tersebut memiliki kelemahan dalam menganalisis praktik security awareness, information privacy, dan security behaviour.[3]

Tujuan dari penelitian ini adalah untuk menganalisis dan mengukur pemahaman Mahasiswa tentang pentingnya pemahaman tentang kebijakan privasi pada layanan publik. Pentingnya pemahaman tentang keamanan informasi demi menjaga data privasi dan meminimalisir tindak kejahatan yang sekarang marak terjadi seperti Cyber Crime atau kejahatan dunia maya dan masalah keamanan informasi lainnya.

\section{METODOLOGI PENELITIAN}

Penelitian dilakukan dengan cara mengumpulkan data hasil survei mahasiswa PTIK UNIMA. Penelitian ini dilakukan secara langsung (tatap muka) maupun secara online (tanpa tatap muka). Metode yang digunakan dalam penelitian ini adalah :

\section{Wawancara}

Proses wawancara dilakukan diarea kampus, khususnya kepada mahasiswa PTIK UNIMA.

\section{Survei (Kuesioner)}

Survei merupakan alternatif metode komunikasi dengan mengajukan pertanyaan pada responden dan merekam jawabannya untuk dianalisis lebih lanjut (Cooper dan Emory,1995). Permasalahan dalam teknik survei lebih terkait dengan pembuatan kuesionernya karena berhubungan langsung dengan daya tanggap responden.[4] Kuesioner merupakan alat pengumpulan data primer dengan metode survei untuk memperoleh opini responden. Kuesioner dapat didistribusikan kepada responden dengan cara: (1) Langsung oleh peneliti (mandiri); (2) Dikirim lewat pos (mailquestionair); (3) Dikirim lewat komputer misalnya surat elektronik (email).[4] dalam survei ini penulis menggunakan jenis kuesioner tertutup atau menggunakan pilihan ganda (lebih dari satu pilihan).

\section{HASIL PENELITIAN}

Berdasarkan metode penelitian yang digunakan, dihasilkan data seperti berikut :

1. Apakah responden membaca kebijakan privasi (privacy policy) dalam suatu layanan publik sebelum menyetujui ketentuan yang ada

Tabel 1. kebijakan privasi

\begin{tabular}{cccc}
\hline No. & Jawaban & Jumlah & Presentase \\
\hline 1. & YA & 30 & $58,8 \%$ \\
\hline 2. & MUNGKIN & 12 & $23,5 \%$ \\
\hline 3. & TIDAK PEDULI & 9 & $17,7 \%$ \\
\hline & Jumlah & 51 & $100 \%$ \\
\hline
\end{tabular}

2. Yakinkah responden dengan keamanan layanan publik yang menyimpan data dan informasi pribadi?

Tabel 2. keamanan layanan publik

\begin{tabular}{cccc}
\hline No. & Jawaban & Jumlah & Presentase \\
\hline 1. & YA & 21 & $41,2 \%$ \\
\hline 2. & MUNGKIN & 25 & $49 \%$ \\
\hline 3. & TIDAK PEDULI & 5 & $9,8 \%$ \\
\hline & Jumlah & 51 & $100 \%$ \\
\hline
\end{tabular}

3. Yakinkah responden dengan pertanyaan pertanyaan yang meminta persetujuan anda yang mengatas namakan keamanan data dan informasi dalam layanan publik?

Tabel 3. pertanyaan meminta persetujuan

\begin{tabular}{cccc}
\hline No. & Jawaban & Jumlah & Presentase \\
\hline 1. & YA & 18 & $35,3 \%$ \\
\hline 2. & MUNGKIN & 27 & $53,9 \%$ \\
\hline 3. & TIDAK PEDULI & 6 & $11,8 \%$ \\
\hline & Jumlah & 51 & $100 \%$
\end{tabular}


4. Apakah responden menyadari resiko yang dapat terjadi terkait dengan informasi pribadinya. (Dicuri pihak tak berwewenang).

Tabel 4. menyadari resiko

\begin{tabular}{cccc}
\hline No. & Jawaban & Jumlah & Presentase \\
\hline 1. & YA & 38 & $74,5 \%$ \\
\hline 2. & MUNGKIN & 7 & $13,7 \%$ \\
\hline 3. & TIDAK PEDULI & 6 & $11,8 \%$ \\
\hline & Jumlah & 51 & $100 \%$ \\
\hline
\end{tabular}

5. Apakah responden menyadari pentingnya perlindungan privasi?

Tabel 5. perlindungan privasi

\begin{tabular}{cccc}
\hline No. & Jawaban & Jumlah & Presentase \\
\hline 1. & YA & 46 & $90,2 \%$ \\
\hline 2. & MUNGKIN & 3 & $5,9 \%$ \\
\hline 3. & TIDAK PEDULI & 2 & $3,9 \%$ \\
\hline & Jumlah & 51 & $100 \%$ \\
\hline
\end{tabular}

6. Apakah anda memahami resiko terhadap pelanggaran privasi?

Tabel 6. memahami resiko

\begin{tabular}{cccc}
\hline No. & Jawaban & Jumlah & Presentase \\
\hline 1. & YA & 31 & $60,8 \%$ \\
\hline 2. & MUNGKIN & 15 & $29,4 \%$ \\
\hline 3. & TIDAK PEDULI & 5 & $9,8 \%$ \\
\hline & Jumlah & 51 & $100 \%$ \\
\hline
\end{tabular}

Pentingnya meningkatkan kesadaran mahasiswa maupun masyarakat tentang keamanan informasi guna untuk menghindari resiko kerugian seperti kebocoran informasi, penyalahgunaan data pribadi, pemalsuan identitas, dan hal-hal yang dapat menimbulkan kerugian terhadap pengakses layanan public.
Langkah dasar untuk menjaga privasi dan keamanan data pribadi :

1. Selalu cek update dan jaga kebersihan perangkat, sebisa mungkin untuk rutin mengupdate system operasi. Selain update, kamu juga perlu rajin membersihkan perangkatmu dari virus.

2. Gunakan kata sandi (password) yang unik dan solid. Gunakan kata sandi yang seunik mungkin dan terus perbaharui minimal tiga bulan sekali. Semakin unik, tekateki kata sandi semakin sulit dipecahkan oleh peretas.

3. Mengakses internet dengan aman, selalu gunakan HTTPS

4. Mengetahui dan memantau di mana saja anda menyimpan data

5. Evaluasi segala usaha anda, terus terapakan langkah dasar untuk menjaga privasi. Perlu diingat juga bahwa privasi bukan hanya soal diri sendiri, tetapi juga orang-orang terdekat anda. Enkripsi komunikasi harus dilakukan dari ujung ke ujung, dari pengirim ke penerima, jadi ajak orang-orang terdekat anda untuk mengadopsi langkah-langkah di atas agar bisa saling melindungi informasi pribadi.

\section{KESIMPULAN}

Berdasarkan hasil survey yang dilakukan dapat disimpulkan bahwa sebagian besar mahasiswa menyadari pentingnya keamanan privasi dalam layanan public, mahasiswa juga menyadari resiko yang dapat terjadi jika melakukan pelanggaran dalam kebijakan privasi orang lain. Namun tidak sedikit juga mahasiswa yang merasa tidak peduli dengan keamanan privasi mereka. Maka dari itu, perlu adanya sosialisasi dan pengenalan lebih luas mengenai keamanan informasi dan kebijakan privasi dikalangan mahasiswa maupun di masyarakat. 


\section{REFERENSI}

[1] Saeful, "Keamanan Informasi," 2014.

[2] "Privasi \& Keamanan di Internet Bab 1 :"

[3] I. A. Afandi, A. Kusyanti, and N. H.Wardani, "Analisis Hubungan Kesadaran Keamanan , Privasi Informasi , Perilaku Keamanan Pada Para Pengguna Media Sosial Line," vol. 1, no. 9, pp. 783-792, 2017.

[4] I. Pujihastuti, "Prinsip penulisian kuesioner penelitian," Agribisnis dan Pengemb. Wil., vol. 2, no. 1, pp. 43-56, 2010.

[5] J. R. Batmetan Suyoto, J. D. C. L. Suares, "An Empirical Investigation on Customer Behavior to Adopt Mobile Commerce among the Y Generation in Indonesia", Sriwijaya International Conference On Engineering, Science \& Technology [SICEST 2016], 2016

[6] J.R. Batmetan, "Algoritma Ant Colony Optimization (ACO) untuk Pemilihan Jalur Tercepat Evakuasi Bencana Gunung Lokon Sulawesi Utara", Jurnal Teknologi Informasi-AITI, 2016, vol.13, no.2, pp 3148

[7] L. Madeso, D. R. Kabo, J. R. Batmetan, " Rancang Bangun Sistem Pakar Penentuan Status Gizi Pada Balita Menggunakan Metode Forward Chainning", E-Jurnal UNSRIT, vol.2

[8] J. R. Batmetan, V. R. Palilingan, " Higher Education Students' Behaviour to Adopt Mobile Learning", IOP Conference Series: Materials Science and Engineering, 2018, vol. 306, Issue 1, pp. 012110 (2018)

[9] V. R. Palilingan, J. R. Batmetan, " Incident Management in Academic Information System using ITIL Framework", IOP Conference Series: Materials Science and Engineering, 2018, vol. 306, Issue 1, pp. 012110 (2018)

[10] J. R. Batmetan, A. J. Santoso, Pranowo, " A Multiple-Objective Ant Colony Algorithm for Optimizing Disaster Relief Logistics",
Advanced Science Letters, 2017, vol.23, no.3, pp. 2344-2347

[11] M. L. Tompodung, F. Supit, J. R. Batmetan, " Rancang Bangun Aplikasi Sensus Penduduk Berbasis Android", Buletin Sariputra, 2017, vol.7, pp. 57-61

[12] J. R. Batmetan, " Optimasi Strategi Smart Environment Dalam Mitigasi Bencana Menggunakan Multi-Objective Aco (MoAco) Algorithm", Pasca Sarjana Magister Teknik Informatika Universitas Atma Jaya Yogyakarta, 2016 